\title{
MPPT ALGORITHM BASED ON PV CELL TEMPERATURE, USING OPEN CIRCUIT VOLTAGE MEASUREMENT, COMBINED WITH PV CELL COOLING
}

\author{
Nuno M. M. da Rocha ${ }^{1}$, Lucas L. Brighenti ${ }^{1}$, Júlio César Passos ${ }^{2}$, Denizar C. Martins ${ }^{1}$ \\ ${ }^{1}$ Federal University of Santa Catarina, Electrical Engineering Department, INEP, Florianópolis - Santa Catarina, Brazil \\ ${ }^{2}$ Federal University of Santa Catarina, Mechanical Engineering Department, LEPTEN, Florianópolis - Santa Catarina, Brazil \\ e-mail: nuno.ahcor@gmail.com, lucasbrighenti@gmail.com, denizar@inep.ufsc.br, julio.passos@ufsc.br
}

\begin{abstract}
As an increase of Photovoltaic (PV) cell temperature originates a negative effect, the application of a PV cell cooling system allows a performance improvement. Therefore, the present work aims to investigate the performance of a PV module transformed into a Photovoltaic/Thermal (PV/T) module, producing electrical and thermal energy simultaneously, while concurrently establishing a cooling system for the PV cells. The $P V$ conversion efficiency is affected by modifications of the operation conditions particularly the ones concerning PV cell temperature and radiation due to the displacement of the system Maximum Power Point (MPP). In the present work the Maximum Power Point Tracking (MPPT) is performed using an algorithm based exclusively on PV cell temperature information with the particularity that the temperature measurements are perform without the use of any temperature sensors. The studied system performance is compared to a conventional PV using the same MPPT algorithm. The results show that the cooling system associated to the MPPT temperature based algorithm provides a bigger energy output leading to higher economic savings. In addition, it can help simplifying the MPPT algorithm by allowing the use of slower dynamic.
\end{abstract}

Keywords - MPP, MPPT, Photovoltaic, Photovoltaic Cell Cooling, Photovoltaic Cell Temperature.

\section{NOMENCLATURE}

$\begin{array}{ll}A & \text { PV Cell Module Area. } \\ B R L & \text { Brazilian Real. } \\ \text { CEff } & \text { Conversion Efficiency. } \\ \text { CEff } & \text { Conversion Efficiency Improvement. } \\ C_{i} & \text { Input Capacitor. } \\ C_{o} & \text { Output Capacitor. } \\ C_{p} & \text { Water Specific heat. } \\ C V & \text { Constant Voltage. } \\ D & \text { Duty Cycle. } \\ D_{M P P} & \text { Maximum Power Point Duty Cycle. } \\ E s & \text { Economic Savings. } \\ G & \text { Module Incident Solar Radiation } \\ I & \text { Current. } \\ \text { IncCond } & \text { Incremental Conductance. }\end{array}$

\footnotetext{
Manuscript received 23/03/2018; first revision 29/05/2018; accepted for publication 17/08/2018, by recommendation of Editor Marcello Mezaroba. http://dx.doi.org/10.18618/REP.2018.4.2804
}

\begin{tabular}{|c|c|}
\hline$L$ & Inductor. \\
\hline$\dot{m}$ & Water Mass Flow Rate. \\
\hline$M P P$ & Maximum Power Point. \\
\hline$M P P T$ & Maximum Power Point Tracking. \\
\hline NTC & Negative Temperature Coefficient. \\
\hline OEO & Overall Output Energy. \\
\hline OPеo & Overall Electrical Output Power. \\
\hline$O P_{O}$ & Overall Output Power. \\
\hline$P \& O$ & Perturb and Observe. \\
\hline $\mathrm{Peo}$ & Electrical Output Power. \\
\hline$P V$ & Photovoltaic. \\
\hline$P V / T$ & Photovoltaic/Thermal. \\
\hline$Q_{P V / T}$ & Circulating Water. \\
\hline STC & Standard Test Conditions. \\
\hline$T$ & Temperature. \\
\hline$T_{f b}$ & Temperature Fluid Out. \\
\hline$T_{f t}$ & Temperature Fluid Inlet. \\
\hline$T_{P V}$ & Photovoltaic Cell Temperature. \\
\hline$T_{P V}^{S T C}$ & $\begin{array}{l}\text { Photovoltaic Cell Temperature on Standard } \\
\text { Test Conditions. }\end{array}$ \\
\hline$V$ & Voltage. \\
\hline$V_{M P P}$ & MPP Voltage. \\
\hline$V_{o c}$ & Open Circuit Voltage. \\
\hline$V_{o c}^{S T C}$ & $\begin{array}{l}\text { Open Circuit Voltage on Standard Test } \\
\text { Conditions. }\end{array}$ \\
\hline$V_{\text {out }}$ & Converter Output Voltage. \\
\hline $\mathrm{V}_{\mathrm{PV}}$ & PV Module Voltage. \\
\hline$W_{s}$ & Wind Speed. \\
\hline$W_{T E M P}$ & Water Temperature. \\
\hline$\Delta T_{P V}$ & PV Cell Temperature Difference. \\
\hline$\eta$ & Efficiency Conversion. \\
\hline$\mu_{o c}$ & Open Circuit Temperature Coefficient. \\
\hline
\end{tabular}

\section{INTRODUCTION}

The conversion of solar energy into electrical energy is accomplished using a Photovoltaic (PV) cell, which is affected by the operational conditions, particularly the ones concerning cell temperature and radiation levels as they directly affect the system output power. An increment in radiation levels enhances the output power while an increase in temperature reduces it [1].

High levels of solar radiation denote more energy. However, it also means high PV cell temperature leading to a cutback of the PV system true potential, due to the negative effect of temperature rising. Thus, in recent years many works have focused on increasing the PV system efficiency through PV cell temperature influence[2]-[4]. 
Alterations on the solar radiation levels and PV cell temperature originate the displacement of the PV system Maximum Power Point (MPP). Therefore, in order to guarantee that the PV system constantly operates on its MPP, many works suggest the use of Maximum Power Point Tracking (MPPT) algorithms. There are numerous MPPT algorithms each one using different kinds of inputs [5]-[9], the most common use voltage and/or current measurements. However, some of the newest MPPT algorithms suggest using the PV cell temperature as an input to determine the MPP [8], [10], [11].

In light of the aforementioned, one realizes that a way to maximize the PV module efficiency would be by combining a PV cell cooling technique with an MPPT algorithm based on the cell temperature.

A solar collector known as Photovoltaic/Thermal (PV/T) or hybrid has the ability to combine a PV module and thermal collector into a single unit, producing electrical and thermal energy simultaneously by performing a heat extraction from the PV cells. Therefore, the present work aims to analyse and compare the performance of a conventional PV module transformed into a PV/T, by simply attaching a heat exchanger, where water flows, to the PV module back surface. That way, the PV module becomes capable of producing electrical and thermal energy simultaneously, while concurrently establishing a cooling system for the $\mathrm{PV}$ cells. The $\mathrm{PV} / \mathrm{T}$ module performance is compared to a conventional PV using the same MPPT algorithm, which is based exclusively on PV cell temperature information.

The PV cell temperature measurements are performed without the use of any temperature sensors, rather through measuring only the PV module Open Circuit Voltage $\left(V_{o c}\right)$.

The study of a PV module transformed into a PV/T and the combination of a cooling system with an MPPT algorithm based exclusively on PV cell temperature, without the use of any temperature sensor, has not yet been presented in literature before.

This paper begins by presenting a small explanation on how the PV module performance is affected by operation conditions. Afterwards, it is introduced the MPPT temperature open circuit voltage method, followed by a small literature survey about PV cooling. Subsequently, the experimental setup is described and lastly, the system analysis results are presented as well as suggestions for future research works.

\section{PV MODULE CHARACTERISTICS}

A PV module yields a unique Current (I) - Voltage (V) generation curve according to the levels of solar incident radiation and PV cells temperature. As presented in Figure 1 the location of the MPP moves randomly along the I-V plan as result of the verified changes in PV cells temperature and irradiation levels [11].

The MPP moves horizontally (along the $\mathrm{V}$ axis) for temperature changes and vertically (along the I axis) for irradiance changes as presented in Figure 2 and 3 , respectively. An increase in PV cell temperature originates the translation of the MPP towards the left, while an increase in irradiation levels moves it upwards [8], [11]. Therefore, an increase of irradiation originates a power growing while a PV cell temperature rising leads to a power decrease.

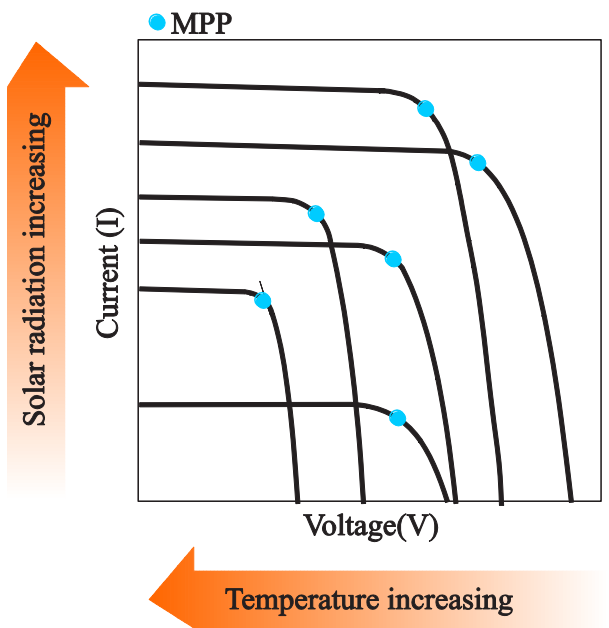

Fig. 1. MPP across the $\mathrm{I}-\mathrm{V}$ plan considering solar radiation and temperature changes [10].

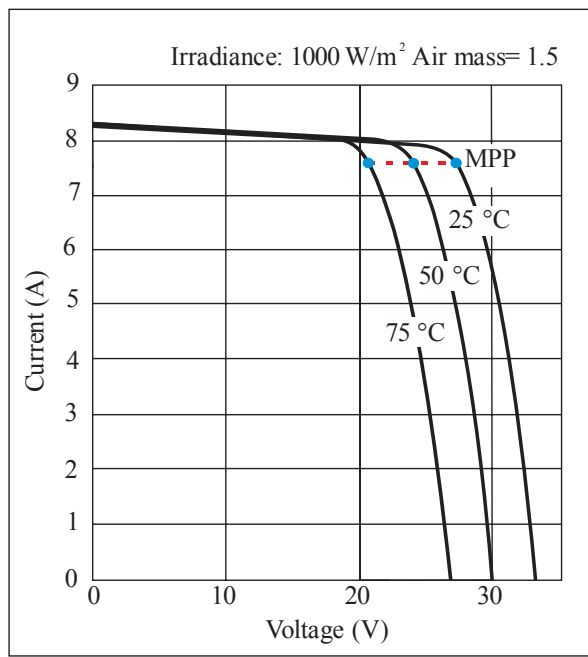

Fig. 2. I-V curve from Kyocera KC200GT PV module under constant irradiance.

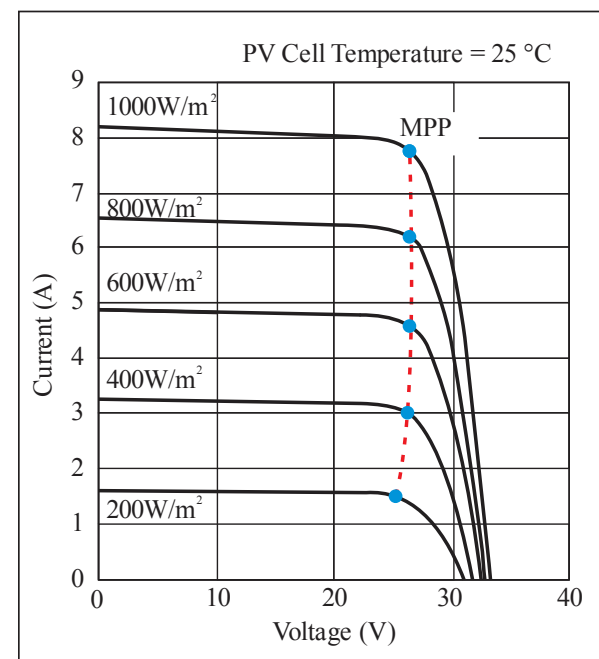

Fig. 3. I-V curve from Kyocera KC200GT PV module under constant PV cell temperature. 


\section{MAXIMUM POWER POINT TRACKING SYSTEMS}

The MPPT algorithms purpose is to ensure that the PV module operates constantly in its MPP, according to PV cell temperature and solar radiation levels. Typically, the MPPT is achieved by interposing a converter between the PV module and the load, where from the voltage and/or current measurements, the MPPT algorithm calculates the converter optimal Duty Cycle (D) in order to ensure MPP operation [6], [7], [12], [13]. Figure 4, presents a typical configuration of an MPPT system using a DC-DC type converter.

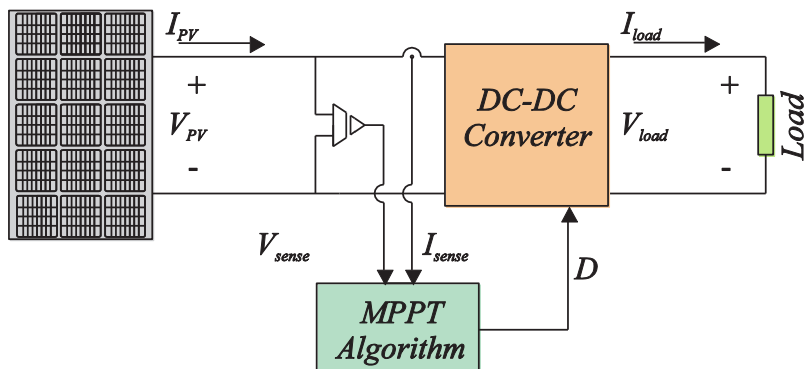

Fig. 4. Typical DC-DC converter MPPT configuration [11].

Typical algorithms used to determine the MPP are Perturb and Observe (P\&O), Incremental Conductance (IncCond), Constant Voltage (CV) and PV cell temperature based, even though many others exist in literature [8], [9].

An interesting alternative to the typical MPPT algorithms is the use of an MPPT algorithm based on PV cell temperature, where the problem concerning PV cell temperature variation, which severely modifies the MPP, can be avoided [8] .

The main advantage of the MPPT based on PV cell temperature algorithm is to unify the simplicity of implementation of the $\mathrm{CV}$ method with the velocity and accuracy tracking of the IncCond one [11]. However, temperature sensing in practical implementations can be a problematic issue due to irregular distribution of PV array temperature [5]. This problem can be avoided by measuring the PV module $V_{o c}$.

\section{A. MPPT Temperature - Open Circuit Voltage}

In the MPPT-temp $V_{o c}$ method, the PV Cell Temperature $\left(T_{P V}\right)$ is inferred uniquely from the PV module $V_{o c}$, considering (1) [14], where $V_{o c}{ }^{S T C}$ represents the PV module $V_{o c}$ and $T_{P V}$ STC the PV cell Temperature, both on Standard Test Conditions (STC: PV cell temperature $25^{\circ} \mathrm{C}$; irradiance $1000 \mathrm{~W} / \mathrm{m}^{2}$; air mass 1.5$)$, and $\mu_{o c}$ the open circuit temperature coefficient.

Looking at (1) it is clear that PV cell temperature depends uniquely of PV module parameters. From that information, and using (2) [8], [11], [14], the MPP Voltage $\left(V_{M P P}\right)$ is determined.

$$
\begin{gathered}
T_{P V}=\frac{V_{o c}-V_{o c}^{S T C}}{\mu_{o c}}+T_{P V}{ }^{S T C} \\
V_{M P P}\left(T_{P V}\right)=V_{M P P}\left(T_{P V}{ }^{S T C}\right)+\left(T_{P V}-T_{P V}{ }^{S T C}\right) \mu_{o c} .
\end{gathered}
$$

The MPPT PV cell temperature based method is similar to the constant voltage method and for this reason it is simple to implement [8]. By using $V_{o c}$ measurements to determine the $\mathrm{PV}$ module temperature the issue concerning the irregular distribution of PV array temperature is overcome.

Figure 5 shows an example of an MPPT-temp $V_{o c}$ DC-DC converter implementation.

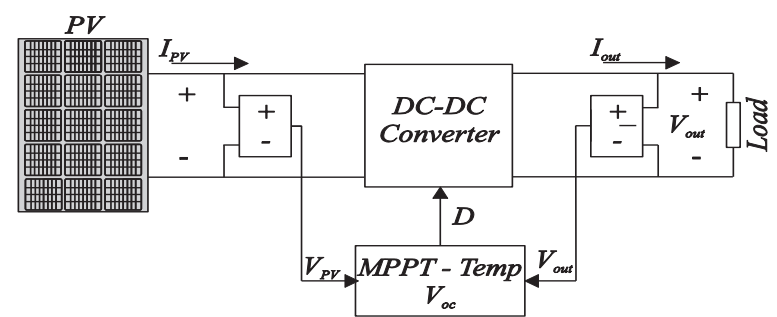

Fig. 5. MPPT-temp $V_{O C}$ DC-DC converter example implementation [14].

After determining the MPP voltage, using the sensor measured Output Voltage $\left(V_{\text {out }}\right)$, the converter D is set using the correspondent gain equation.

This MPPT algorithm can be considered simpler than the commonly used algorithms, since it requires the use of only two voltage sensors. One to measure the PV Module Output Voltage $\left(V_{P V}\right)$ and other to measure the load voltage [16]. In addition, even though it is a temperature based MPPT algorithm, it dismisses the use of temperature sensors. It stands out that the practical implementation of the voltage sensors can be accomplished by means of a voltage divider.

\section{PV CELL COOLING}

The PV cells are capable of absorbing up to $80 \%$ of the incident solar radiation. However, only a small percentage of this energy is converted into electricity, depending on the PV cell material. In this manner, the remainder energy is dissipated in the form of heat [15].

High ambient temperature is normally associated with high radiation conditions leading to the increasing of PV cell temperature [16]. Therefore, due to the negative effects, associated with PV cell temperature rising, the main focus of several publish works has been finding ways of achieving a lower operation temperature, as comprehended by the published related reviews [2]-[4].

One of the ways to reduce the temperature and take advantage of the dissipated heat is through a PV/T system. It combines PV cells and a thermal collector into a single unit, thus allowing the production of electrical and thermal energy concurrently by removing the heat dissipated from the PV cells. As the thermal energy is produced, through heat extraction from the PV cells, an improvement in efficiency conversion occurs, mainly due to a temperature decrease. The PV/T collector has a higher energy efficiency than the two systems working separately [17], [18].

There are different types of PV/T collectors with different configurations, although their main principle remains the same. The most common PV/T systems are the water and air based ones.

The PV/T water based systems perform best than the air based ones, due to the higher heat conduction ratio of the 
water [19]-[21]. Thereby, a water PV/T system was chosen for the present study.

\section{PV CELL COOLING AND MPPT}

As the PV module performance is severally affected by local environmental conditions, which are constantly changing, it would be interesting to combine an MPPT with a heat removal technique, whereas the information regarding the PV module temperature could be used by a MPPT method that uses an algorithm based on temperature control.

The use of a PV cell cooling system or heat removal technique allows the opportunity to use an MPPT temperature based algorithm while simultaneously enhancing the PV performance. However, most of the works, despite performing a PV cell temperature analysis, discard the importance of the employed an MPPT algorithm and the thermal information is not used to find and impose the MPP as the PV system operation point.

The studies that perform some kind of a temperaturerelated analysis and mentioned the use of an MPPT technique are [22]-[24]. However, the MPPT applied techniques, in those studies, do not use the PV cell temperature to perform the MPPT.

Moharram et al. [22] achieved the cooling of the PV module through the circulation of water on the front surface of the module, but the data concerning the PV cells module temperature is not used as an input to perform the MPPT. Instead, a P\&O algorithm is applied to find the MPP.

Jardan et al. [23] also performed the study of PV/T collector, combined with an MPPT device. Nevertheless, that device uses an algorithm based on voltage and current outputs.

Bahaidarah et al. [24] executed PV module cooling by circulating water on the back surface of the module. The system efficiency and performance improvement is analyzed and it is mentioned the use of a commercial MPPT device. However, this MPPT device does not consider any information regarding the $\mathrm{PV}$ cell module temperature, in order to achieve the MPP.

Finally, Baloch et al [25] attached a converging thermal collector to the back surface of a PV to reduce PV cell module temperature. The employed commercial MPPT operates without a PV cell temperature input.

A system that is able to influence PV cell temperature can be combined with an MPPT algorithm based on temperature control, in order to determine and ensure MPP operation. Hence, it is believed that a PV/T system can be used to perform a temperature control of the PV cells, simplifying the MPPT algorithm, while at the same time providing an overall performance improvement, due to low PV cell temperature.

Given the above, it is clear the absence of any work that performs PV cell cooling and uses the PV cell temperature as an input to perform the MPPT through an algorithm, based on PV cell temperature control. Therefore, the main contribution of the present work is the study of a systems that combines a PV cell cooling technique with an MPPT temperature based algorithm.

\section{PROPOSED SYSTEM}

As perceived in Figure 3 the MPP voltage remains practically constant, regardless of the variations occurred in the irradiation levels, providing that the PV cell temperature is preserved [10]. Therefore, a PV cell cooling system can help simplifying the MPPT algorithm by allowing the use of slower dynamic. As long as the system load behaves as a constant voltage source.

\section{A. Experimental Setup}

The experimental setup is composed of two KC200GT PV modules, where in one of those modules a heat exchanger was attached to the back surface through were water flows thus establishing a cooling system for the PV cells and creating a PV/T module. The setup is shown in Figure 6 and a schematic diagram is presented in Figure 7.

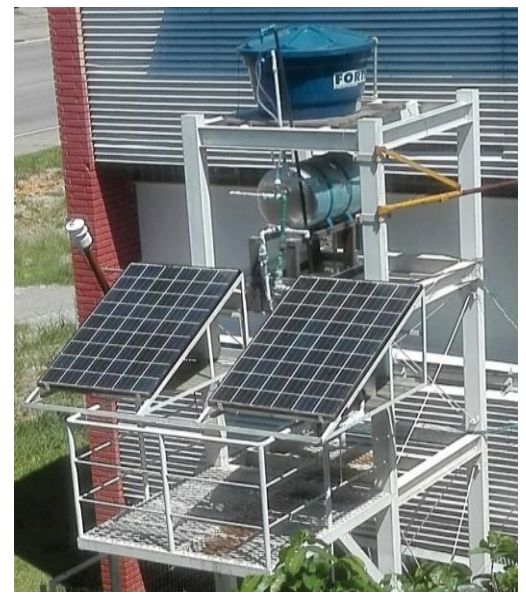

Fig. 6. Experimental setup of the two KC200 PV modules.

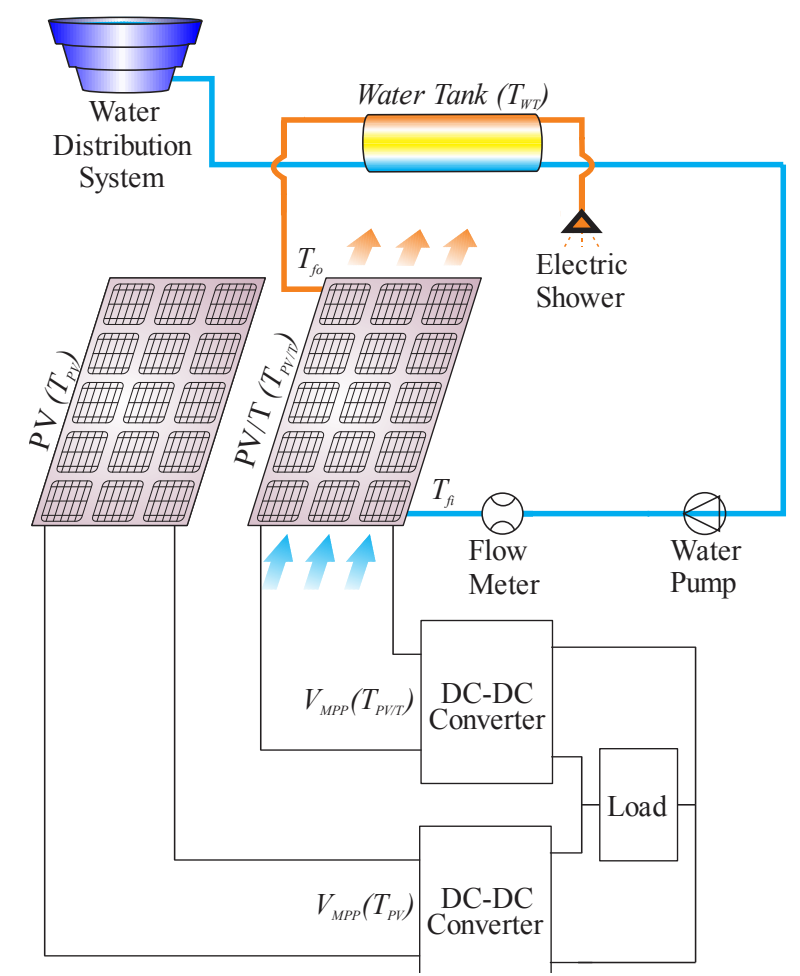

Fig. 7. Schematic diagram of the experimental setup. 
All measured system variables were recorded using an Agilent 34972A data logger (sampling time of 10 seconds) whereas for climatic data, it was used an LUFFT WS501-DT weather station. The climatic data was measured with a sampling time of 5 seconds, providing a mean value for each 10 minutes. The monitored climatic variables are irradiation, ambient air temperature and wind speed (Ws). The Ws was monitored because of its significant influence in PV cell temperature due to its effect on the convection heat transfer coefficient, between the glass cover and ambient air [26] [28].

1) Cooling setup: The cooling system objective is restraining PV cell temperature rise and keep it as constant as possible. A $55 \mathrm{~W}$ water pump $(\mathrm{GP}-100 \mathrm{C} / \mathrm{CB})$ is responsible for imposing the water flow through the heat exchanger, using grid power, providing a mean flow rate of $4.21 \mathrm{l} / \mathrm{min}$. The cooling water exits the tank, captures the PV cells wasted heat, and returns to the water tank (100 1), allowing heat storage and water recirculation. Consequently, there is no water renewal, therefore, the system operates as a closed system.

Water flow rate is measured with a flow meter, and the inlet and outlet water temperatures are measured using $10 \mathrm{k} \Omega$ Negative Temperature Coefficient (NTC) type thermistors.

The PV module back surface and the heat exchanger are shown in Figures 8.a and 8.b, respectively, in addition, the heat exchanger parameters are given in Table I.

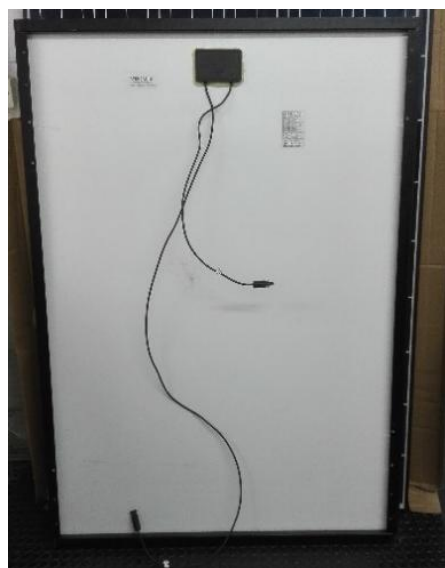

(a)

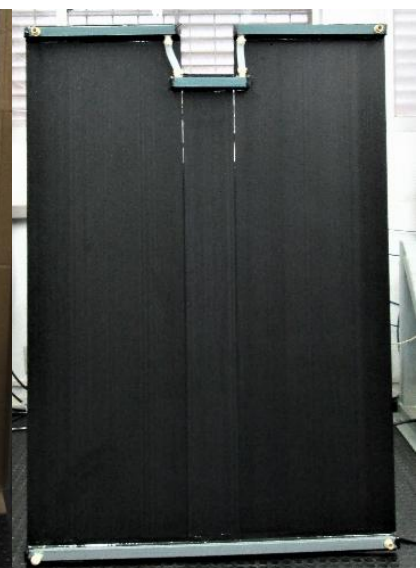

(b)
Fig. 8. (a) PV module back surface and (b) heat exchanger.

TABLE I

Heat Exchanger Parameters

\begin{tabular}{cc}
\hline Parameter & Value \\
\hline Manufacturer & Soluzenergia \\
\hline Area & $1.31\left(\mathrm{~m}^{2}\right)$ \\
\hline Water volume & $2(\mathrm{~L})$ \\
\hline Material & Polypropylene \\
\hline Working Fluid & Water \\
\hline Flow rate & $3-100(1 / \mathrm{h})$ \\
\hline Maximum Working Pressure & $1(\mathrm{Bar})$ \\
\hline
\end{tabular}

The PV module heat exchanger back surface fixation, which transforms the $\mathrm{PV}$ module into a $\mathrm{PV} / \mathrm{T}$, is presented in Figure 9.a, whereas in Figure 9.b are highlighted the different $\mathrm{PV} / \mathrm{T}$ module components for a better understanding. In green is emphasized the module aluminum frame, in blue the heat exchanger and in red the heat exchanger back surface fixing brackets.

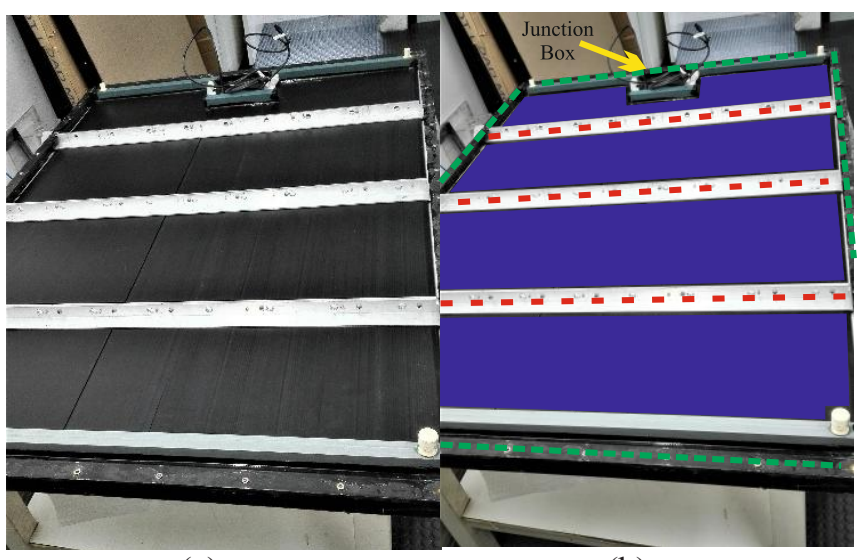

(a)

(b)

Fig. 9. (a) PV back surface fixing and (b) highlighted PV/T module components.

2) Electrical setup: Both PV modules are connected to their own DC-DC Boost type converter which are linked to a battery bank composed of eight $12 \mathrm{~V}$ battery associated in series/parallel making a total of $48 \mathrm{~V}$. The schematic of the two used Boost converter is shown in Figure 10 and their specifications are present in Table II where, it can be comprehended that the two converter differ only in the value of inductor. So, any significant difference on performance is expected.

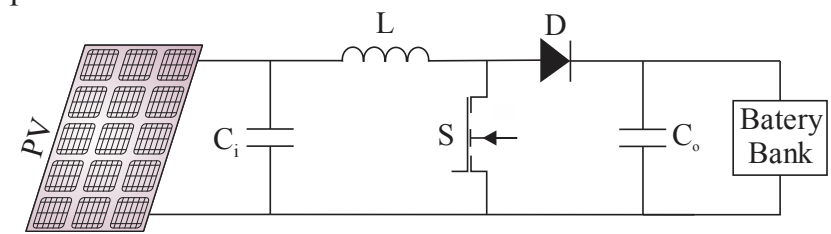

Fig. 10. Boost converter schematic.

TABLE II

Boost Converter Specifications

\begin{tabular}{ccc}
\hline Converter & Boost PV/T & Boost PV \\
\hline Inductor $(\mathrm{L})$ & $311.3 \mu \mathrm{H}$ & $309.6(\mu \mathrm{H})$ \\
\hline Input Capacitor $\left(\mathrm{C}_{\mathrm{i}}\right)$ & $220(\mu \mathrm{F})$ \\
\hline Output Capacitor $\left(\mathrm{C}_{\mathrm{o}}\right)$ & $2200(\mu \mathrm{F})$ \\
\hline Switching frequency & $50(\mathrm{kHz})$ \\
\hline MPPT Algotithm & Temp $-V_{o c}$ \\
\hline
\end{tabular}

The used MPPT algorithm is the Temperature $-V_{o c}$ and its flow chart is presented in Figure 11. First the converter D is set to zero (interrupt $=1$ ), so that the PV cell temperature difference $\left(\Delta T_{P V}\right)$ can be inferred, through the acquisition of the $V_{o c}$ and the PV module parameters. At the end of the interruption the duty cycle $\left(D_{M P P}\right)$, that ensures PV module MPP operation, is calculated [14]. The KC200GT PV module parameters are given in Table III.

To infer the PV cells temperature, it is necessary to assure that the system remains in open circuit for a minimum time, required for the PV module parallel placed input capacitor to reach full charge [14] . In this study case, the converter D is kept at zero for a period of 0.375 seconds. As temperature changes are not as dynamic as the ones in radiation, the interruptions to determine the MPP were set to be 30 seconds apart. 


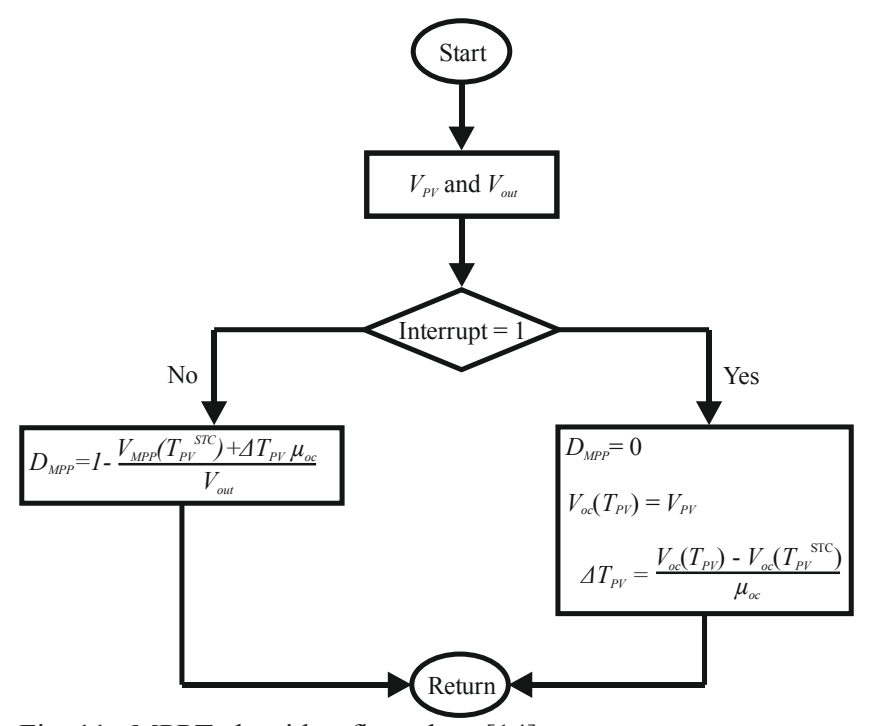

Fig. 11. MPPT algorithm flow chart [14].

TABLE III

KC200GT PV Module Electrical Specifications

\begin{tabular}{cl}
\hline Parameter & Value \\
\hline Manufacturer & Kyocera \\
\hline Maximum power & $200(\mathrm{~W})$ \\
\hline$\mu_{o c}$ & $-0.123\left(\mathrm{~V} /{ }^{\circ} \mathrm{C}\right)$ \\
\hline$T_{P V}{ }^{S C}$ & $25\left({ }^{\circ} \mathrm{C}\right)$ \\
\hline$V_{o c}\left(T_{P V} S T C\right.$ & $32.9(\mathrm{~V})$ \\
\hline$V_{M P P}\left(T_{P V}{ }^{S T C}\right)$ & $26.3(\mathrm{~V})$ \\
\hline
\end{tabular}

\section{RESULTS AND ANALYSIS}

The electrical measured variables were PV module open circuit voltage, for PV cell temperature calculation using (1), and electrical power. In Figure 12 is shown the test bench.

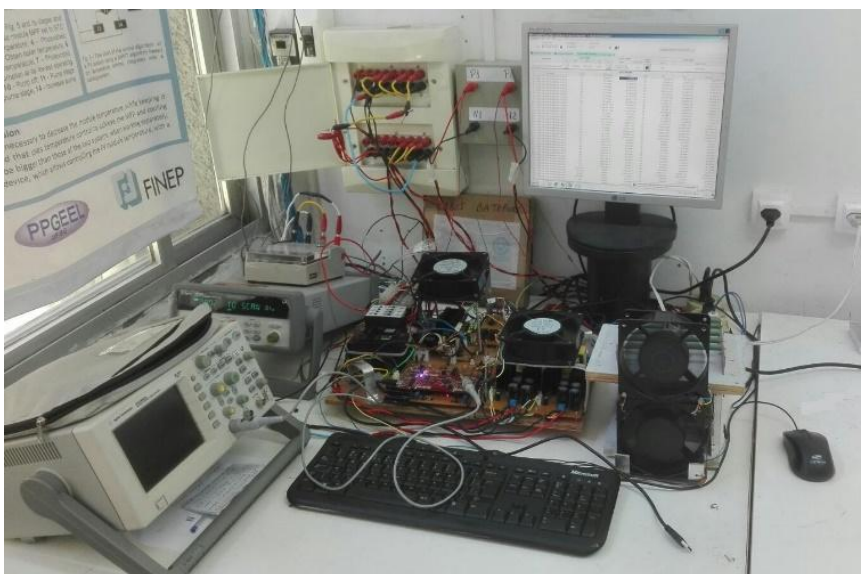

Fig. 12. Test bench.

The experiment was performed on September, 222017 at the Power Electronics Institute at Federal University of Santa Catarina, south of Brazil. Figures 13, 14 and 15 show the hourly radiation, ambient temperature and Ws curves, respectively, recorded during the experiment. The data was recorded between 10:00 and 14:00 hours, because this is the insolation period available at the test site due to shadowing issues as consequence of nearby buildings.

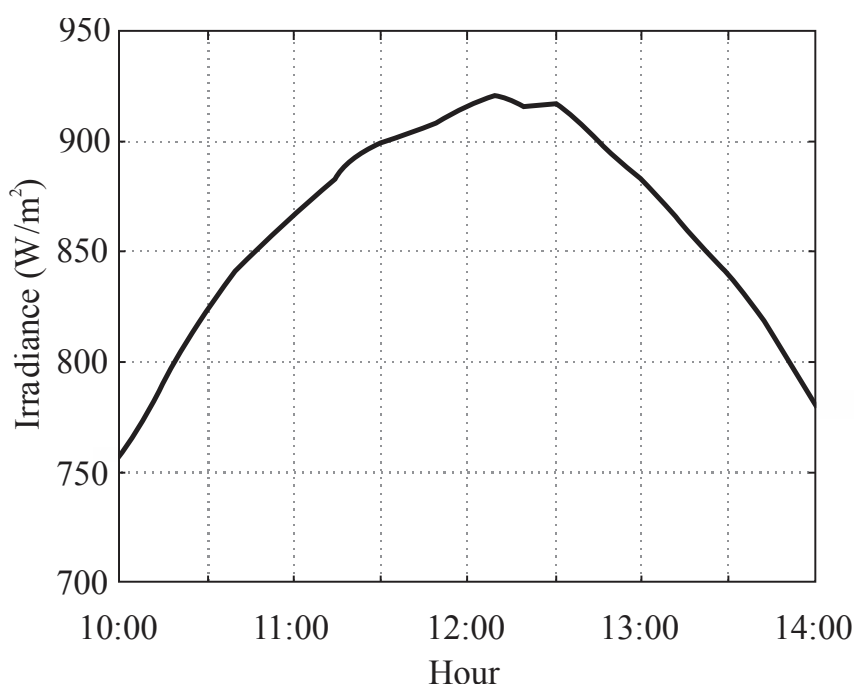

Fig. 13. Hourly radiation during September, 22 of 2017.

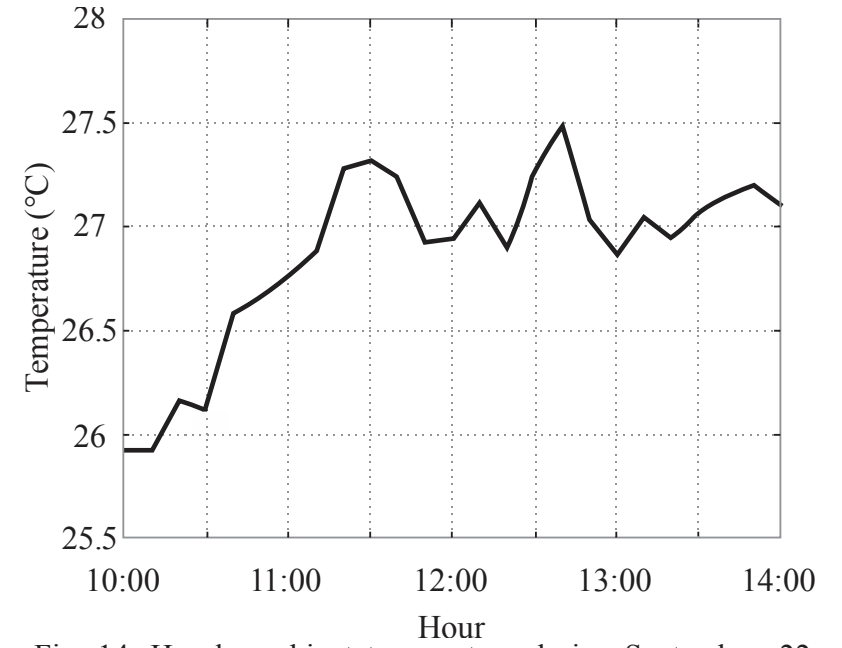

Fig. 14. Hourly ambient temperature during September, 22 of 2017.

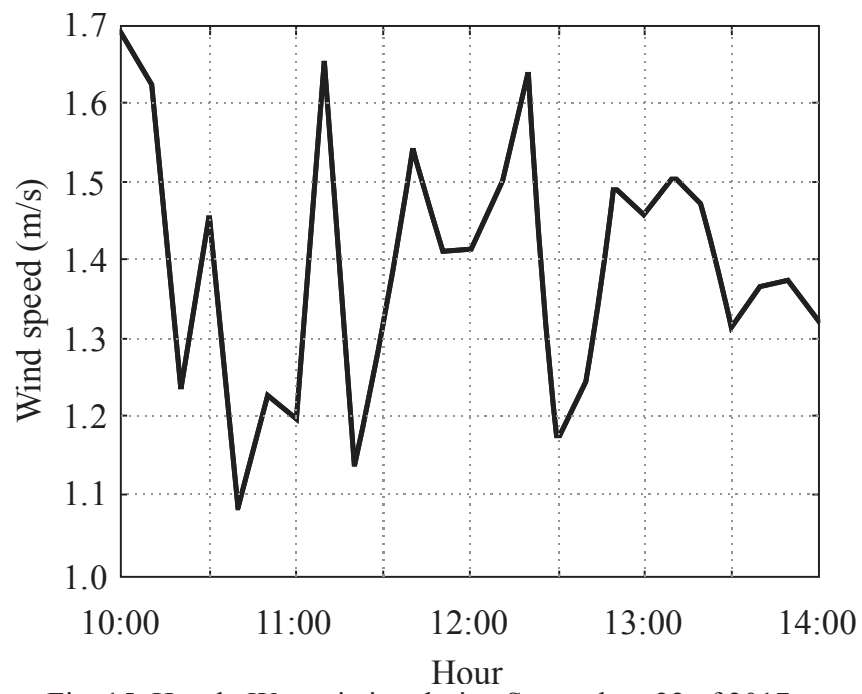

Fig. 15. Hourly Ws variation during September, 22 of 2017.

Figure 16 demonstrates the Temperature $(\mathrm{T})$ curves observed in PV cells for both the PV and PV/T system and Ws. It is clear that the cooling system was able to reduce the cell temperature, as well as assuring that it is less affected by the sudden changes in Ws. 


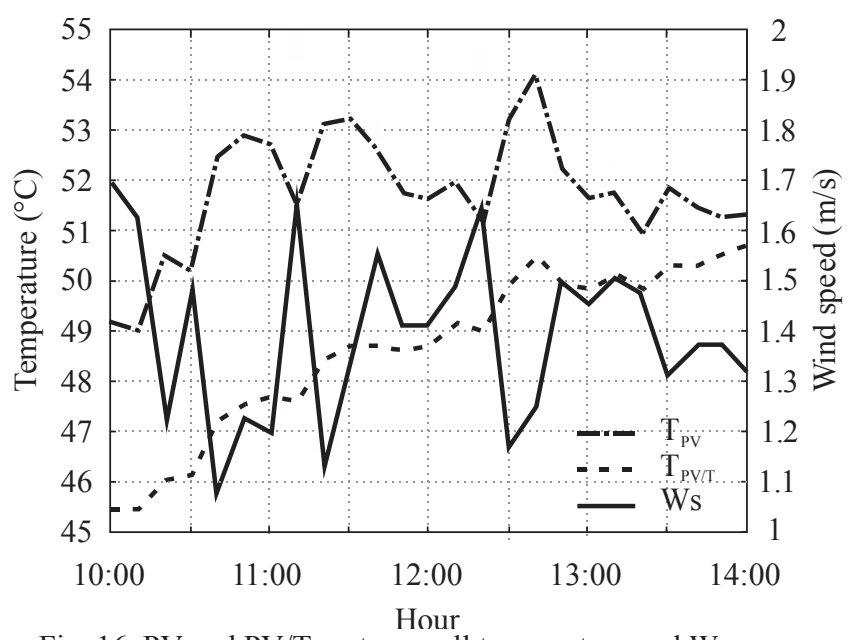

Fig. 16. PV and PV/T systems cell temperature and Ws.

However, when the temperature of the PV module cells begins to decrease, due to the reduction in the irradiation levels, the $\mathrm{PV} / \mathrm{T}$ module temperature keeps rising leading to an approximation of the two module temperatures at the end of the day. This is due to the fact that the water mass thermal inertia hinders the $\mathrm{PV} / \mathrm{T}$ heat lost to the environment which may lead to a cut back in the electric output power at the end of the day.

Figure 17 demonstrates the Electrical Output Power (Peo) for each system. As expected, due to a lower PV cell operating temperature, the $\mathrm{PV} / \mathrm{T}$ provided power is higher. However, the PV/T system uses a water pump to provide fluid circulation. Therefore, it is necessary to perform a system energy balance, in order to determine the real output power. In other words, it is necessary to determine the difference between the electrical power delivered by the $\mathrm{PV} / \mathrm{T}$ system and water pump consumption.

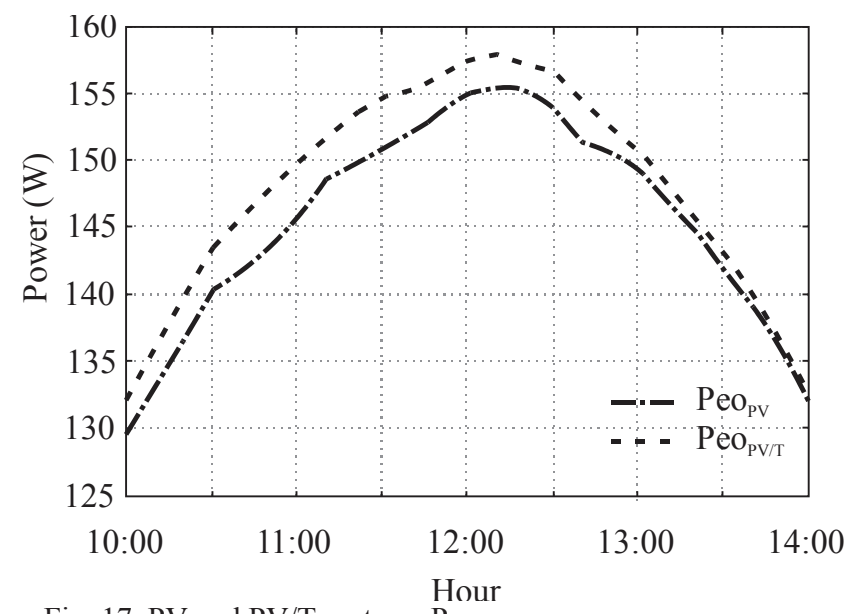

Fig. 17. PV and PV/T systems Peo.

Figure 18 shows the Overall Electrical Output Power (OPeo), which takes into account pump consumption. It is clear that the use of the water pump originates a deficit in the electrical overall output power of $\mathrm{PV} / \mathrm{T}$ system despite its higher Po due to a lowest PV Cell operation temperature.

As mentioned before, a PV/T module produces electrical and thermal energy. Thus, the output energy of the overall system is obtained by taking into account those two types of energy. The rate of thermal energy $(Q)$ transferred from the
$\mathrm{PV} / \mathrm{T}$ module to the circulating water was obtained through (3) where $\dot{m}$ is the water mass flow rate, $C p$ the water specific heat, $T_{f o}$ and $T_{f i}$ temperature fluid out and inlet, respectively.

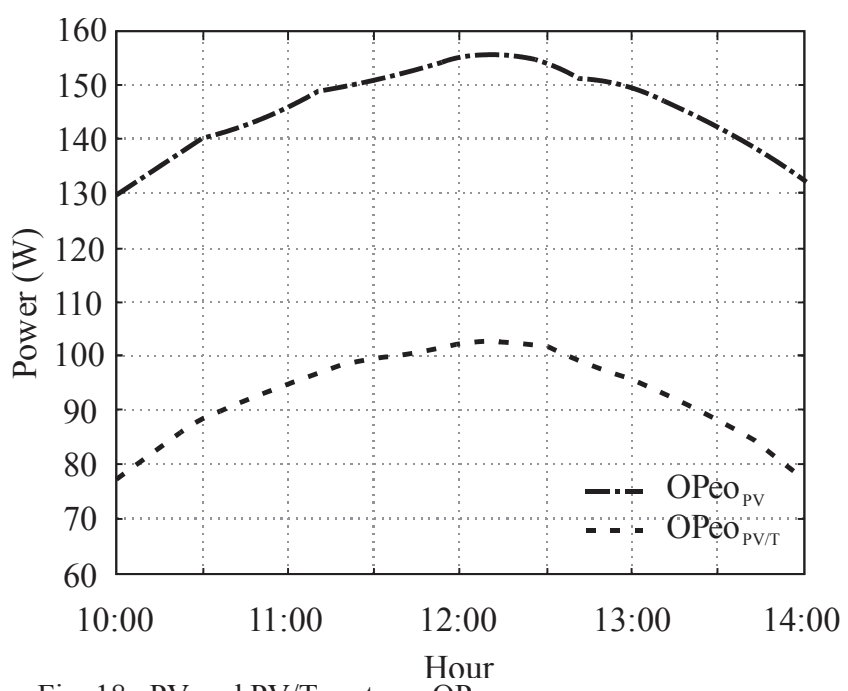

Fig. 18. PV and PV/T systems OPeo.

$$
Q_{P V / T}=\dot{m} \cdot C p \cdot\left(T_{f o}-T_{f i}\right) .
$$

Figure 19 exhibits the PV/T thermal energy output power and the cooling Water Temperature $\left(\mathrm{W}_{\text {TEMP }}\right)$. It is clear that as the thermal energy is gathered the water temperature rises confirming the production of thermal energy.

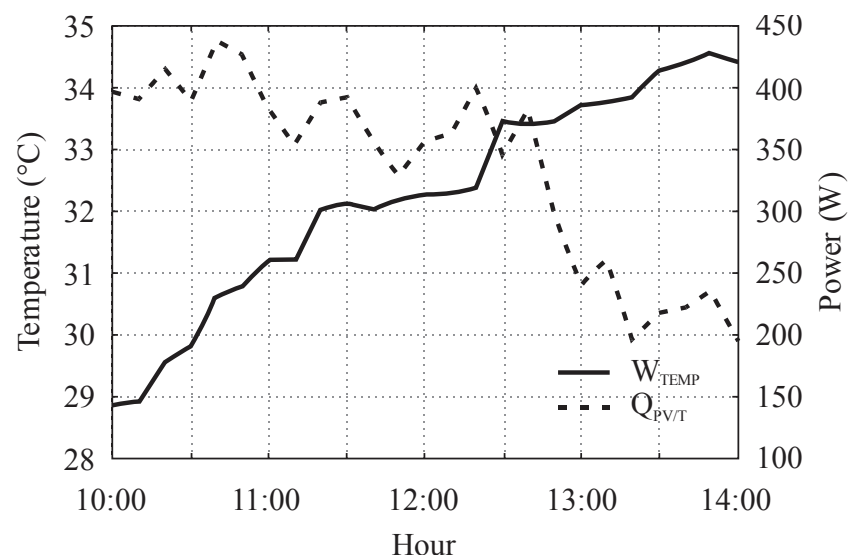

Fig. 19. PV/T thermal energy output power and cooling $\mathrm{W}_{\text {TEMP. }}$

Figure 20 presents the generation curves concerning the Overall Output Power (OPo) of the PV and PV/T systems. For the calculation of the PV/T system output power, the water pump power consumption was taken into account and withdrawn from the produced power. However, despite of the water pump consumption, the $\mathrm{PV} / \mathrm{T}$ system provides a higher OPo when compared to the PV system.

The power conversion efficiency of solar systems is defined as the ratio of the output power by the total module incident power [29]. Thus, the Efficiency Conversion $(\eta)$ is given by (4) where $A$ represent the PV cell module area and $G$ the module incident solar radiation. 


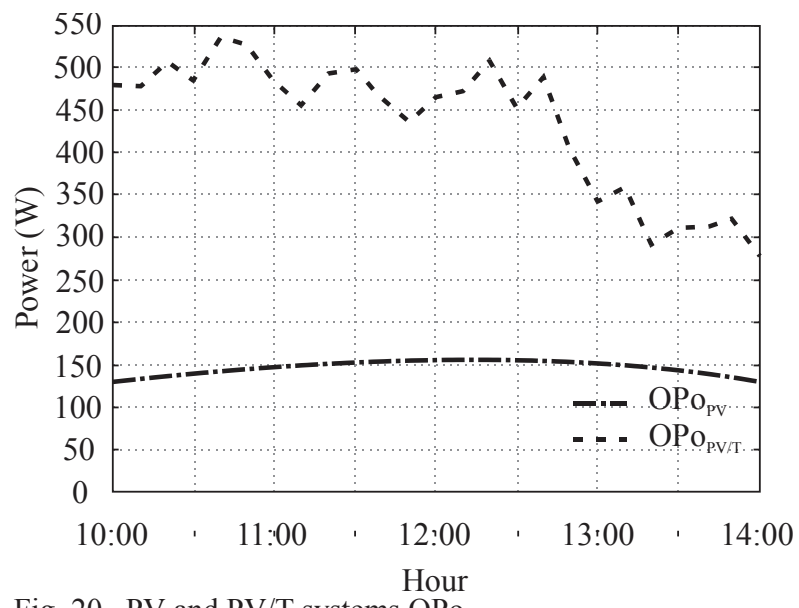

Fig. 20. PV and PV/T systems OPo.

$$
\eta=\frac{O P o}{A \cdot G} .
$$

Figure 21 shows the Conversion Efficiency (CEff) for both $\mathrm{PV}$ and $\mathrm{PV} / \mathrm{T}$ systems as well as the Conversion Efficiency Improvement $\left(\mathrm{CEff}_{\mathrm{I}}\right)$ provided by the transformation of the $\mathrm{PV}$ module into a $\mathrm{PV} / \mathrm{T}$. It is clear that the use of the heat exchanger allows a significant efficiency improvement. If the thermal energy is applied to reduce the electrical energy consumption, for example of an electric shower or boiler, the produced thermal energy can be accounted for as an electric energy gain. Meaning that the use of the heat exchanger can produce a substantial improvement, providing there is a local need for thermal energy.

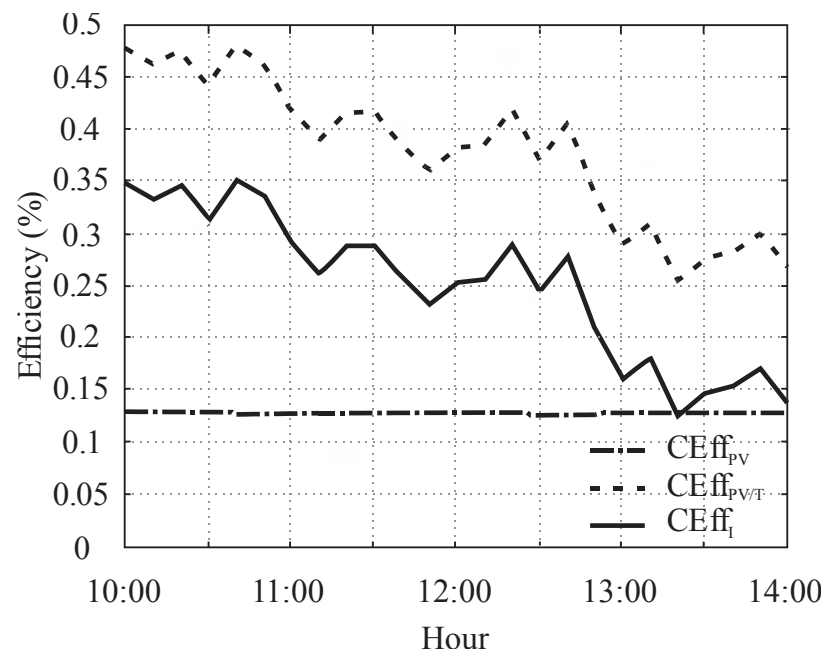

Fig. 21. PV and PV/T systems CEff and CEff.

Figure 22 demonstrates the Overall Output Energy (OEo) and the correspondent Economic Savings (Es) for the PV/T and PV system, considering the OPo. As expected, the PV/T system presents a superior energy gain, which consequently leads to higher Es. The Es were calculate considering the value of 0.45985 Brazilian Real (BRL)/kWh as informed by the electricity utility for the southern Brazilian state of Santa Catarina (CELESC) for normal residential B1 type consumer for the city of Florianopolis, Santa Catarina, Brazil [30]. It was considered that all produced energy was consumed. For instance, the thermal energy would be used to reduce the load of an electrical boiler or shower, commonly used in Brazil.

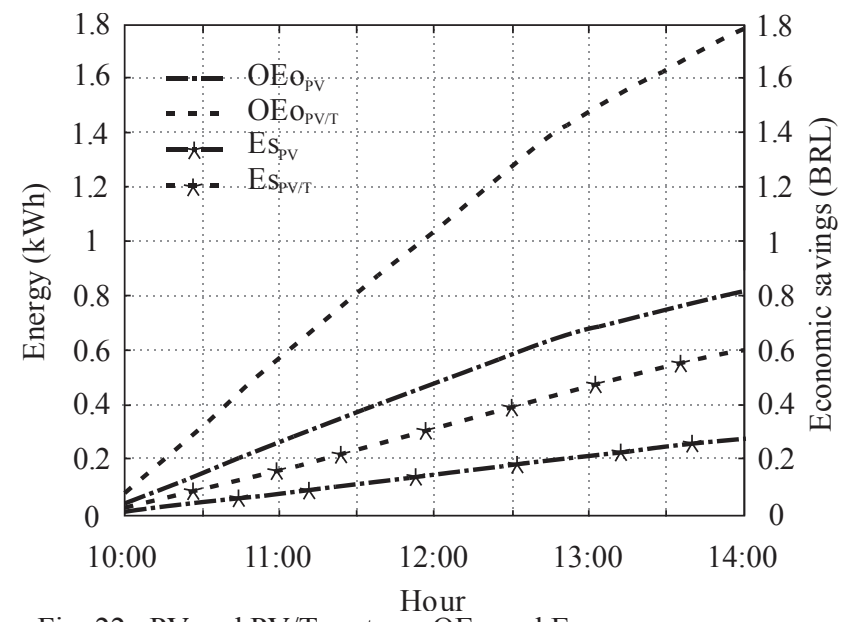

Fig. 22. PV and PV/T systems OEo and Es.

Figure 23 shows the MPP voltage for the PV and PV/T module. It is noticeable that the variations present in the MPP voltage are more evident and abrupt in the case of the PV module. This leads one to believe that the cooling system can help simplify the MPPT algorithm by smoothing the MPP voltage adjustments, therefore allowing the use of slower dynamic.

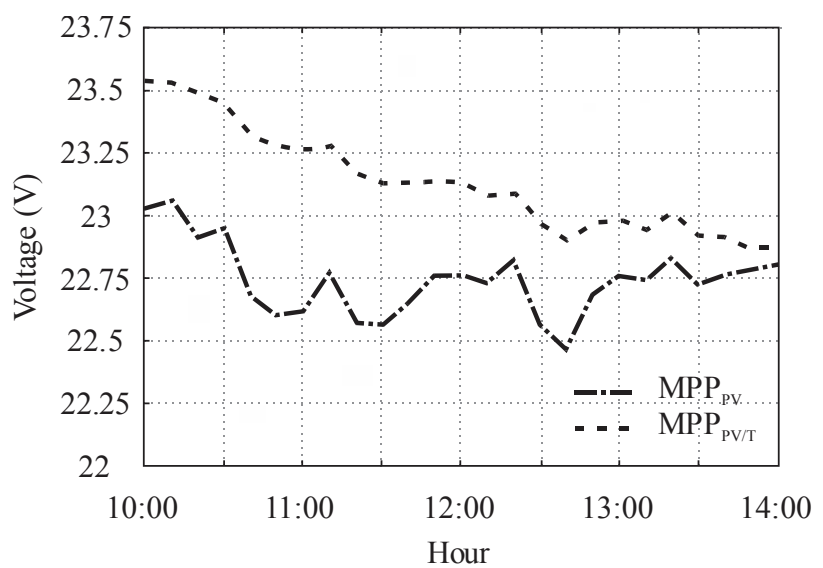

Fig. 23. PV and PV/T systems MPP voltage.

Figure 24 presents the DC-DC Boost converter D variation. It is clear that the converter of the $\mathrm{PV} / \mathrm{T}$ system exhibits a not so abrupt $\mathrm{D}$ modification.

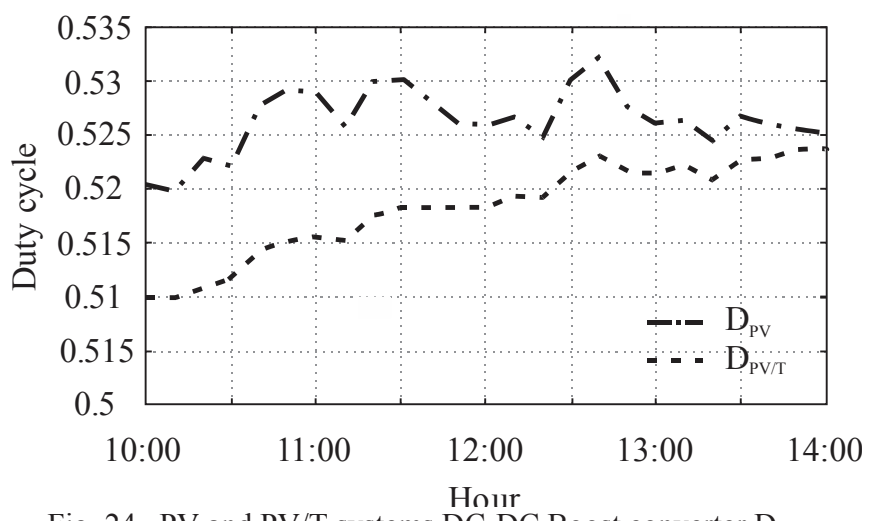

Fig. 24. PV and PV/T systems DC-DC Boost converter D. 


\section{CONCLUSION}

The analysed system has the disadvantage of the electrical consumption regarding the water pump, which yields a deficit on the electrical production of the system. Also, the water mass thermal inertia hinders a natural PV cell temperature decrease for the $\mathrm{PV} / \mathrm{T}$ system which may lead to a cut back in the electric output power at the end of the day.

On the other hand, the PV/T system overall output power vastly exceeds the PV system. This is due to its capacity to produce thermal and electrical energy simultaneously.

From the energy point of view, the studied system provides a higher benefit, which consequently leads to larger economic savings, considering that there is a local need for thermal energy, thereby allowing, for example, the load reduction of an electrical boiler or shower.

The use of the cooling system reduces the amplitude of sudden MPP voltage changes, due to a slower temperature variation, therefore, permitting a MPPT algorithm simplification as result of a slower alteration on the converter D.

In light of the attained results, it is believed that the combination of a MPPT temperature based algorithm with a cooling system allows an energy and economic performance improvement while at the same time enabling the simplification of the MPPT algorithm. Therefore, the main contribution of the present work is to control the technology of electricity and heat generation from a single source (cogeneration), through a simple adaptation of a common a PV module into a $\mathrm{PV} / \mathrm{T}$, combined with an MPPT PV cell temperature based algorithm. In addition, by performing such transformation it is noticeable a decrease in the PV cell temperature oscillation, smoothing the MPP voltage and D adjustments, which facilitates and simplifies the design of the MPPT.

As suggestions for future works, the authors propose an analysis of the effects of thermal inertia on the electrical performance of the $\mathrm{PV}$ and $\mathrm{PV} / \mathrm{T}$ system, and the conduction of a performance and economic analysis that considers the capital, operation and maintenance costs, for a long operation period, per example: for a period of 20 years using typical meteorological year data.

\section{ACKNOWLEDGMENT}

The authors thank CAPES, CNPq and FINEP for the financial support that made this work possible.

\section{REFERENCES}

[1] N. M. da Rocha, R. F. Coelho, J. C. Passos, and D. C. Martins, "Suggestion of associating a PV MPPT algorithm based on temperature control with a PV cooling system", in Renewable Power Generation Conference (RPG 2014), pp. 1-6, 2014.

[2] J. J. Michael, I. S, and R. Goic, "Flat plate solar photovoltaic-thermal (PV/T) systems: A reference guide", in Renewable and Sustainable Energy Reviews, vol. 51, pp. 62-88, Nov. 2015.
[3] S. Nižetić, A. M. Papadopoulos, and E. Giama, "Comprehensive analysis and general economicenvironmental evaluation of cooling techniques for photovoltaic panels, Part I: Passive cooling techniques", in Energy Conversion and Management, vol. 149, pp. 334-354, Oct. 2017.

[4] S. Nižetić, E. Giama, and A. M. Papadopoulos, "Comprehensive analysis and general economicenvironmental evaluation of cooling techniques for photovoltaic panels, Part II: Active cooling techniques", in Energy Conversion and Management, vol. 155, pp. 301-323, Jan. 2018.

[5] M. A. G. de Brito, L. Galotto, L. P. Sampaio, G. de Azevedo e Melo, and C. A. Canesin, "Evaluation of the Main MPPT Techniques for Photovoltaic Applications", in IEEE Transactions on Industrial Electronics, vol. 60, no. 3, pp. 1156-1167, Mar. 2013.

[6] G. M. S. Azevedo, M. C. Cavalcanti, K. C. Oliveira, F. A. S. Neves, and Z. D. Lins, "Comparative Evaluation of Maximum Power Point Tracking Methods for Photovoltaic Systems", in J. Sol. Energy Eng., vol. 131, no. 3, pp. 031006-031006, Jun. 2009.

[7] J. Lopez-Seguel, S. I. J. Seleme, P. Donoso-Garcia, L. F. Morais, P. Cortizo, and M. S. Mendes, "Comparison of MPPT approaches in autonomous photovoltaic energy supply system using DSP", in IEEE International Conference on Industrial Technology (ICIT), pp. 1149-1154, 2010.

[8] M. A. G. de Brito, L. P. Sampaio, G. A. e Melo, and C. A. Canesin, "Contribuição ao Estudo dos Principais Algoritmos de Extração da Máxima Potência dos Painéis Fotovoltaicos", in Eletrônica de PotênciaSOBRAEP, vol. 17, no. 3, pp. 592-600, Aug. 2012.

[9] P. de A. J. Sobreira, F. L. Tofoli, H. A. C. Braga, P. G. Barbosa, and A. A. Ferreira, "Analysis of Mppt Techniques Applied to the DCM Multiphase Boost Converter for the Mitigation of Partial Shading in $\mathrm{Pv}$ Arrays", in Eletrônica de Potência-SOBRAEP, vol. 18, no. 4, pp. 1138-1148, Nov. 2013.

[10] R. Francisco and D. Cruz, "An Optimized Maximum Power Point Tracking Method Based on PV Surface Temperature Measurement", in Sustainable Energy Recent Studies, A. Gebremedhin, Ed. InTech, 2012.

[11] R. F. Coelho, F. M. Concer, and D. C. Martins, "A MPPT approach based on temperature measurements applied in PV systems", in IEEE/IAS International Conference on Industry Applications (INDUSCON), pp. 1-6, 2010.

[12] D. C. Martins, C. L. Weber, and R. Demonti, "Photovoltaic power processing with high efficiency using maximum power ratio technique", in IEEE Conference of the Industrial Electronics Society (IECON), Sevilla, Spain, vol. 2, pp. 1079-1082, 2002.

[13] M. M. Casaro and D. C. Martins, "Application of the Three-phase Series Resonant Converter in a DualStage Inverter Operating without Specific Sensor to Perform the MPPT", in Conference of the IEEE Industrial Electronics Society (IECON), pp. 1650 $1655,2007$. 
[14] D. L. S. Solano, "Sistema de Supervisão e Controle de Geração Solar Fotovoltaica para Aplicação em Microrredes Inteligentes", Dissertação de mestrado, Universidade Federal de Santa Catarina, Florianopolis, Brazil, 2016.

[15] W. G. J. van Helden, R. J. C. van Zolingen, and H. A. Zondag, "PV thermal systems: PV panels supplying renewable electricity and heat", in Progress in Photovoltaics: Research and Applications, vol. 12, no. 6, pp. 415-426, Sep. 2004.

[16] Z. Peng, M. R. Herfatmanesh, and Y. Liu, "Cooled solar PV panels for output energy efficiency optimisation", in Energy Conversion and Management, vol. 150, pp. 949-955, Oct. 2017.

[17] K. Moradi, M. Ali Ebadian, and C.-X. Lin, "A review of PV/T technologies: Effects of control parameters", in International Journal of Heat and Mass Transfer, vol. 64, pp. 483-500, Sep. 2013.

[18] A. Makki, S. Omer, and H. Sabir, "Advancements in hybrid photovoltaic systems for enhanced solar cells performance", in Renewable and Sustainable Energy Reviews, vol. 41, pp. 658-684, Jan. 2015.

[19] M. A. Hasan and K. Sumathy, "Photovoltaic thermal module concepts and their performance analysis: A review", in Renewable and Sustainable Energy Reviews, vol. 14, no. 7, pp. 1845-1859, Sep. 2010.

[20] A. S. Joshi, I. Dincer, and B. V. Reddy, "Performance analysis of photovoltaic systems: A review", in Renewable and Sustainable Energy Reviews, vol. 13, no. 8, pp. 1884-1897, Oct. 2009.

[21] X. Zhang, X. Zhao, S. Smith, J. Xu, and X. Yu, "Review of R\&D progress and practical application of the solar photovoltaic/thermal (PV/T) technologies", in Renewable and Sustainable Energy Reviews, vol. 16, no. 1, pp. 599-617, Jan. 2012.

[22] K. A. Moharram, M. S. Abd-Elhady, H. A. Kandil, and H. El-Sherif, "Enhancing the performance of photovoltaic panels by water cooling", in Ain Shams Engineering Journal, vol. 4, no. 4, pp. 869-877, Dec. 2013.

[23] R. K. Jardan, I. Nagy, A. Cid-Pastor, R. Leyva, A. El Aroudi, and L. Martinez-Salamero, "Combined Photovoltaic / Thermal Energy System for Stand-alone Operation", in IEE International Symposium on Idustrial Electronics, pp. 2403-2408, June 2007.

[24] H. Bahaidarah, A. Subhan, P. Gandhidasan, and S. Rehman, "Performance evaluation of a PV (photovoltaic) module by back surface water cooling for hot climatic conditions", in Energy, vol. 59, pp. 445-453, Sep. 2013.

[25] A. A. B. Baloch, H. M. S. Bahaidarah, P. Gandhidasan, and F. A. Al-Sulaiman, "Experimental and numerical performance analysis of a converging channel heat exchanger for PV cooling", in Energy Conversion and Management, vol. 103, pp. 14-27, Oct. 2015.

[26] B. M. Ziapour, V. Palideh, and A. Mohammadnia, "Study of an improved integrated collector-storage solar water heater combined with the photovoltaic cells", in Energy Conversion and Management, vol. 86, pp. 587-594, Oct. 2014.

[27] A. Tiwari and M. S. Sodha, "Performance evaluation of solar PV/T system: An experimental validation", in Solar Energy, vol. 80, no. 7, pp. 751-759, Jul. 2006.

[28] G. Evola and L. Marletta, "Exergy and thermoeconomic optimization of a water-cooled glazed hybrid photovoltaic/thermal (PVT) collector", in Solar Energy, vol. 107, pp. 12-25, Sep. 2014.

[29] C. A. Matias, L. M. Santos, A. J. Alves, and W. P. Calixto, "Increasing photovoltaic panel power through water cooling technique", in Transactions on Environment and Electrical Engineering - TEEE, vol. 2, no. 1, Feb. 2017.

[30] "CELESC - Centrais Elétricas de Santa Catarina", 2018 [Online]. Available: http://www.celesc.com.br.

\section{BIOGRAPHIES}

Nuno Miguel Martins da Rocha has a Mechanical Engineer degree (2010) and a master's degree in sustainable energy (2012) both from Instituto Superior de Engenharia do Porto (ISEP). Currently is PhD student at the Federal University of Santa Catarina (UFSC) at the Institute of Power Electronics (INEP). His areas of interest are renewable and sustainable energy, thermal systems and energy efficiency.

Lucas Lapolli Brighenti holds a degree and a master's degree from the State University of Santa Catarina (UDESC) (2011 and 2014). He is currently a PhD student at UFSC, developing activities at INEP. He has experience in electrical engineering, with emphasis on electric power systems.

Júlio Cesar Passos mechanical engineer degree from polytechnic school of Federal University of Rio de Janeiro (UFRJ) (1980), master in mechanical engineering from coppe-UFRJ (1984), PhD from the University of Paris Vi (pierre et marie curie) (1989). Professor at the mechanical engineering department of UFSC. Member of the board of trustees of Foundation for Research and University Extension (FAPEU) (2016-2020). He acts as a researcher, master's and $\mathrm{PhD}$ advisor in the area of thermal sciences.

Denizar Cruz Martins has a bachelor's degree with emphasis in electricity (1978), a degree in electrical engineering (1978), a master's degree in electrical engineering (1981) from UFSC and $\mathrm{PhD}$ in electrical engineering from the Institut National Polytechnique de Toulouse, France (1986). He is currently leader of the INEP and professor of the department of electrical engineering of UFSC. He has experience in electrical engineering, with emphasis on power electronics, working mainly on the following topics: static converters cc-cc and cc-ca simulation, power factor correction, power quality, electronic power processing, active distribution and distributed generation. 